\title{
Transcriptional regulation by nonclassical action of thyroid hormone
}

\author{
Lars C Moeller ${ }^{*}$, Martina Broecker-Preuss
}

\begin{abstract}
Thyroid hormone $(\mathrm{TH})$ is essential for normal development, growth and metabolism. Its effects were thought to be principally mediated through triiodothyronine (T3), acting as a ligand for the nuclear TH receptors (TRs) $\alpha$ and $\beta$ residing on thyroid hormone response elements (TREs) in the promoter of TH target genes. In this classical model of TH action, T3 binding to TRs leads to recruitment of basal transcription factors and increased transcription of TH responsive genes.

Recently, the concept of $\mathrm{TH}$ action on gene expression has become more diverse and now includes nonclassical actions of T3 and T4: T3 has been shown to activate PI3K via the TRs, which ultimately increases transcription of certain genes, e.g. HIF-1 $\alpha$. Additionally, both T3 and thyroxine (T4) can bind to a membrane integrin, $\alpha \vee \beta 3$, which leads to activation of the PI3K and MAPK signal transduction pathways and finally also increases gene transcription, e.g. of the FGF2 gene. Therefore, these initially nongenomic, nonclassical actions seem to serve as additional interfaces for transcriptional regulation by TH. Aim of this perspective is to summarize the genes that are currently known to be induced by nonclassical TH action and the mechanisms involved.
\end{abstract}

\section{TH and gene induction by classical mechanisms}

Thyroid hormones (THs) are essential for normal development, growth, and metabolism, especially during fetal development and early childhood. In adults, the primary effects of THs are manifested by alterations in metabolism, including changes in oxygen consumption, protein, carbohydrate, lipid, and vitamin metabolism. The pleiotropic effects of THs on many different pathways and target organs become obvious by the clinical features of hypothyroidism and hyperthyroidism. TH action is mainly understood as modification of gene expression, mediated by the nuclear TH receptors (TRs) $\alpha$ and $\beta$ as ligand dependent transcription factors. In the classical model of gene induction by $\mathrm{TH}$, the TRs are located on thyroid hormone response elements (TREs) in the promoter of target genes, often as homodimers, but also as heterodimers with the retinoid-X receptor (RXR) [1,2]. In the unliganded state, corepressors are bound to the TR complex. Upon T3 binding, TR homodimers dissociate in favor of heterodimer formation. The corepressors are released and replaced by coactivators. This new

\footnotetext{
* Correspondence: lars.moeller@uni-due.de

Department of Endocrinology and Division of Laboratory Research,

University of Duisburg-Essen, Hufelandstr. 55, 45147 Essen, Germany Full list of author information is available at the end of the article
}

complex ultimately engages the RNA polymerase II in transcription of the gene (Fig. $1 \mathrm{~A}$ ).

This model also explains the dominant negative effect of a mutant TR $\beta$ on the wildtype TR in the syndrome of resistance to thyroid hormone (RTH). In $\mathrm{RTH}$, patients have raised serum $\mathrm{TH}$ and raised or inappropriately normal TSH levels. Common clinical features of RTH include goiter, tachycardia, delayed bone growth with a variable phenotype [3]. In the majority of cases, RTH is caused by heterozygous TR $\beta$ gene mutations. One mutant TR $\beta$ as part of a homo- or heterodimer on a TRE could lead to reduced T3-binding, decreased corepressor release or decreased ability to bind coactivators. As a consequence, this TRE is blocked by a transcriptionally inactive TR $\beta$ complex and transcription of its gene is impaired despite the presence of normal TR $\beta$ encoded by the wildtype allele. The mutant TR $\beta$ thus confers a dominant negative effect on the wildtype receptor and consequently inhibits $\mathrm{TH}$ action [4]. An exception to this model is the index family described by Refetoff et al. with autosomal recessive inheritance [5] due to a homozygous deletion of the coding region of the TR $\beta$ gene [6]. Heterozygous members of this family were not affected clinically or biochemically, demonstrating that one wildtype copy of TR $\beta$ is sufficient for
C Biomed Central 




normal function. Until now, no mutations in the $\mathrm{TR} \alpha$ gene have been described [2].

\section{Non-classical TH action}

In the last ten years, large scale microarray studies have been performed to determine the effect of $\mathrm{TH}$ on gene expression in animal and human cells [7-12]. In recent years, it has become evident, that $\mathrm{TH}$ can act through various mechanisms: besides the classical TR/TREmediated mechanism (Fig. $1 \mathrm{~A}$ ) these are the nonclassical mechanism of PI3K activation by either liganded TR $\beta$ (Fig. 1 B) or the integrin $\alpha v \beta 3$ (Fig. 1 C) as well as activation of the MAPK cascade via $\alpha v \beta 3$ (Fig. 1 D) (see below). All these mechanisms potentially influence gene expression. The initial step of pathway activation by $\mathrm{TH}$ is nongenomic, but the consequences include increased transcription of certain genes independent of TREs, which then are nonclassically induced $\mathrm{TH}$ target genes. While microarray studies helped defining gene expression changes in response to $\mathrm{TH}$, their results represent a sum effect of both the classical TRE-dependent and the nonclassical pathway initiated mechanisms of $\mathrm{TH}$ action. It now seems necessary to attribute changes in gene expression to their underlying mechanisms. In this overview we aim to summarize which gene induction could be connected to nonclassical action of TH, especially in human cells (summarized in table 1).

\section{TRs and PI3K activation}

One important nonclassical action of $\mathrm{TH}$ is the activation of PI3K via the liganded TR (Fig. $1 \mathrm{~B}$ ). T3 had been shown to be able to activate the PI3K pathway with downstream phosphorylation and activation of PKB/Akt, mTOR and $\mathrm{p} 70^{\mathrm{S} 6 \mathrm{~K}}\left[{ }^{13}\right]$. This effect of $\mathrm{T} 3$ was initially observed as stimulation of $\mathrm{Na}, \mathrm{K}-\mathrm{ATPase}$ and $\mathrm{KCNH} 2$ activity that could be inhibited by the PI3K inhibitors LY294002 (LY) and wortmannin [14,15]. The crucial role of the TR $\beta$ for activation of PI3K became evident in experiments by $\mathrm{Cao}$ et al. in human skin fibroblasts [13]. Co-immunoprecipitation of both TR $\beta$ and the regulatory subunit of PI3K ( $\mathrm{p} 85 \alpha$ ) demonstrated the association of TR $\beta$ and PI3K. Interestingly, the association 
Table 1 Gene induction attributed to nonclassical action of TH.

\begin{tabular}{|c|c|c|c|c|c|c|c|}
\hline Gene & Proposed initial TH action & Method & Cell/tissue type & $\mathrm{TH}$ & $\begin{array}{l}\text { TH } \\
\text { concentration }\end{array}$ & $\begin{array}{l}\text { time of TH } \\
t x\end{array}$ & Ref. \\
\hline $\begin{array}{l}\text { ZAKI } 4 \alpha \\
\text { (RCAN2) }\end{array}$ & TR $\beta / P I 3 K$ & $\begin{array}{l}\text { microarray/real time PCR/ } \\
\text { Western }\end{array}$ & $\begin{array}{l}\text { primary human skin } \\
\text { fibroblasts }\end{array}$ & $\mathrm{T} 3$ & $2 \mathrm{nM}$ & $24 \mathrm{~h}$ & {$[13,9]$} \\
\hline$H I F-1 \alpha$ a) & TR $\beta / P I 3 K$ & $\begin{array}{l}\text { microarray/real time PCR/ } \\
\text { Western }\end{array}$ & $\begin{array}{l}\text { primary human skin } \\
\text { fibroblasts }\end{array}$ & $\mathrm{T} 3$ & $2 \mathrm{nM}$ & $24 \mathrm{~h}$ & {$[28]$} \\
\hline$H I F-1 \alpha b)$ & $\begin{array}{l}\alpha \vee \beta 3(\mathrm{~S} 1) / \mathrm{P} \mid 3 \mathrm{~K} \text { and } \alpha \vee \beta 3(\mathrm{~S} 2) / \\
\mathrm{ERK} 1 / 2\end{array}$ & RT-PCR & U-87 MG & $\begin{array}{l}\mathrm{T} 3 / \\
\mathrm{T} 4\end{array}$ & $1 \mathrm{nM} / 100 \mathrm{nM}$ & $24 \mathrm{~h}$ & [23] \\
\hline PFKP & $\begin{array}{l}\text { TR } \beta / P I 3 K \text {, target gene of HIF- } \\
1 \alpha\end{array}$ & $\begin{array}{l}\text { microarray/real time PCR/ } \\
\text { Western }\end{array}$ & $\begin{array}{l}\text { primary human skin } \\
\text { fibroblasts }\end{array}$ & $\mathrm{T} 3$ & $2 \mathrm{nM}$ & $24 \mathrm{~h}$ & [28] \\
\hline GLUT1 & $\begin{array}{l}\text { TR } \beta / P I 3 K \text {, target gene of HIF- } \\
1 \alpha\end{array}$ & microarray/real time PCR & $\begin{array}{l}\text { primary human skin } \\
\text { fibroblasts }\end{array}$ & $\mathrm{T} 3$ & $2 \mathrm{nM}$ & $24 \mathrm{~h}$ & {$[28]$} \\
\hline MCT4 & $\begin{array}{l}\text { TR } \beta / P I 3 K \text {, target gene of HIF- } \\
1 \alpha\end{array}$ & microarray/real time PCR & $\begin{array}{l}\text { primary human skin } \\
\text { fibroblasts }\end{array}$ & $\mathrm{T} 3$ & $2 \mathrm{nM}$ & $24 \mathrm{~h}$ & [28] \\
\hline STC-1 & $\begin{array}{l}\text { TR } \beta / P I 3 K \text {, target gene of HIF- } \\
1 \alpha\end{array}$ & microarray/real time PCR & $\begin{array}{l}\text { primary human skin } \\
\text { fibroblasts }\end{array}$ & $\mathrm{T} 3$ & $2 \mathrm{nM}$ & $24 \mathrm{~h}$ & [31] \\
\hline MCL1 & TRß/PI3K & RT-PCR & HK2, HEK293 & $\mathrm{T} 3$ & $100 \mathrm{nM}$, free & $6-24 h$ & [32] \\
\hline FGF2 & MAPK & RT-PCR & ECV304 & $\mathrm{T} 4$ & $100 \mathrm{nM}$ & $6-48 \mathrm{~h}$ & [33] \\
\hline
\end{tabular}

free $=$ serumfree medium

of TR $\beta$ and PI3K is independent of T3, as could be shown in human skin fibroblasts transfected with wildtype TR $\beta$ or with the dominant negative mutant TR $\beta$ G345R that lacks T3-binding property [13] and with native TR $\beta$ in the rat pituitary cell line $\mathrm{GH}_{4} \mathrm{C}_{1}[16]$. But activation of the PI3K/mTOR pathway occurs only after T3 binding because in cells transfected with the TR $\beta$ G345R mutant this pathway was not activated by T3 [11]. Transfection of a dominant negative PI3K p $85 \alpha$ regulatory subunit $(\Delta \mathrm{p} 85 \alpha)$ expectedly also abrogated the T3 effect on the kinases downstream of PI3K, namely Akt, mTOR and $\mathrm{p} 70^{\mathrm{S} 6 \mathrm{~K}}[13]$. Further proof for PI3K activation by TR $\beta$ comes from a RTH mutant TR $\beta$ PV, which constitutively activates PI3K [17].

Unliganded mutant TR $\beta$ is still able to bind to $\mathrm{p} 85 \alpha$ without activating it. The markedly reduced effect of T3 on gene expression in the presence of a mutant TR $\beta$ in RTH is probably due to fact that an already reduced amount of liganded wildtype TR $\beta$ has to compete with unliganded mutant wildtype TR $\beta$ for $\mathrm{p} 85 \alpha$.

Similar results as for the TR $\beta$ were obtained for the TR $\alpha$. Cao et al. could demonstrate PI3K activation by T3 mediated by TR $\alpha$ in TR $\alpha$ overexpressing neuronal cells [18] and Hiroi et al. found TR $\alpha 1$ association with the p85 $\alpha$ subunit of PI3K followed by phosphorylation of Akt and activation of endothelial nitric oxide synthase [19].

\section{$\mathrm{TH}$ and the integrin $\alpha v \beta 3$ receptor}

In 2005, Davis and colleagues identified a structural plasma membrane protein, the integrin $\alpha v \beta 3$, as a TH receptor that activated ERK1/2 [20]. Several lines of evidence supported this finding: radiolabeled $\mathrm{T} 4$ and $\mathrm{T} 3$ could bind to the purified $\alpha v \beta 3$ protein, which was prevented by antibodies against $\alpha \mathrm{v} \beta 3$ as was ERK1/2 activation. SiRNA knockdown of either $\alpha v$ or $\beta 3$ or both inhibited T4-induced MAPK activation. As several other integrins, $\alpha \mathrm{v} \beta 3$ contains a recognition site for the peptide sequence Arg-Gly-Asp (RGD). Pretreatment with an RGD peptide reduced ERK1/2 activation by T4 in the african green monkey fibroblast cell line CV-1. Tetraiodothyroacetic acid (tetrac), a deaminated T4 derivative, also blocked T4 action through the integrin [20]. Furthermore, effects of T4 were reproduced by T4-agarose, a modified thyroxine that does not cross the cell membrane [21]. Subsequent studies dissected sites and mechanisms of $\alpha \mathrm{v} \beta 3$ activation and led to the characterization of two different TH receptor sites, denoted S1 and S2, with different characteristics and intracellular consequences [22].

The S1 site of $\alpha \mathrm{v} \beta 3$ binds only T3 and is activated at physiological concentrations. This leads to phosphorylation and activation of Src and subsequently PI3K (Fig.1 C). T3 action on this site can be blocked by both tetrac and RGD, as demonstrated in human glioblastoma cells (U-87 MG): pretreatment with either RGD peptide or tetrac before addition of T3 abolished Src and PI3K phosphorylation [23]. Treatment with T3 leads to nuclear accumulation of $\mathrm{TR} \alpha$ in a dose dependent manner. This was not observed after pretreatment with the PI3K inhibitor LY.

The other TH binding site on integrin $\alpha \mathrm{v} \beta 3$, S2, binds both $\mathrm{T} 4$ and, to a lesser extent, T3. TH binding to $\alpha v \beta 3 / S 2$ then activates the ERK1/2 pathway (Fig. $1 \mathrm{D}$ ). Both T4 and T3 action can be inhibited by tetrac, but only T4 action by RGD peptide [23]. Results of TH binding to the S2 site of $\alpha v \beta 3$ are increased angiogenesis [20], proliferation of glioma cells [24] papillary and 
follicular thyroid cancer cells [25] and TR $\beta$ shuttling from cytosol to the nucleus [23].

\section{Genes nonclassically induced by TH ZAKI $4 \alpha$}

Activation of PI3K by TR $\beta / \mathrm{T} 3$ and subsequent phosphorylation of downstream protein kinases such as Akt and $\mathrm{p} 70^{\mathrm{S} 6 \mathrm{~K}}$ leads to gene induction (Fig. $1 \mathrm{~B}$ ) and transcriptional regulation by $\mathrm{TH}$ via this pathway could be shown for several genes. ZAKI- $4 \alpha$ (also RCAN2 or DSCR1L1), a calcineurin inhibitor, for example, was already established as a thyroid hormone target gene in human primary fibroblasts but no canonical TRE was found in its promoter [26].

Induction of ZAKI- $4 \alpha$ was attributed to the TR $\beta$ / PI3K-mechanism of TH action, because the T3 effect on ZAKI- $4 \alpha$ was abrogated by pretreatment with PI3Kinhibitors wortmannin and LY294002 and transfection of $\Delta \mathrm{p} 85 \alpha$ [13]. Additionally, an intact TR $\beta$ is required for ZAKI- $4 \alpha$ induction. ZAKI- $4 \alpha$ induction by T3 was abrogated after transfection of a dominant negative TR $\beta$ mutant (G345R) in human fibroblasts [13]. This was further supported by a blunted response to T3 in fibroblasts from patients with RTH either due to a heterozygous TR $\beta$ mutation or homozygous TR $\beta$ deletion compared to that in normal fibroblasts [9]. Pretreatment with cycloheximide (CHX) to prevent translation abrogated the T3 effect on ZAKI4 $\alpha$ mRNA increase, demonstrating the requirement of prior de novo protein synthesis. In time course experiments, ZAKI $4 \alpha$ mRNA accumulation in human primary fibroblasts was significantly increased only after 6 to 12 hours of T3 treatment $[9,26]$. ZAKI $\alpha \alpha$ is therefore indirectly induced by $\mathrm{TH}$ and the mediating transcription factor, representing the immediate link to the PI3K pathway, has yet to be determined.

\section{HIF-1 $\alpha$}

Among the genes found to be induced by T3 in a microarray study in human primary fibroblasts was Hypoxia inducible factor (HIF)-1 $\alpha$ [9], one subunit of the basic helix-loop-helix transcription factor HIF-1. HIF-1 is a key mediator of angiogenesis and metabolic adaptation to hypoxia in tumors. It is responsible for elevated expression of glycolytic enzymes and glucose transporters. The HIF-1 $\beta$ subunit is constitutively expressed, while HIF-1 $\alpha$ is tightly regulated [27]. HIF$1 \alpha$ synthesis is regulated by both PI3K and MAPK pathways, which themselves are activated by receptor tyrosine kinases or G-protein-coupled receptors. Ligands for these include growth factors and hormones such as growth factors and hormones EGF, IGF-1, insulin and androgens. T3 treatment in physiological concentrations was also found to increase HIF- $1 \alpha$ mRNA and protein levels. T3 induced HIF- $1 \alpha$ in normal fibroblasts, but not in fibroblasts from patients with RTH due to a TR $\beta$ mutation (A317T), indicating that the TR $\beta$ is required for this induction. Pretreatment with the PI3K inhibitor LY abrogated the T3 effect on both mRNA and protein, whereas inhibition of the MAPK pathway by PD98059 (PD) had no effect in primary human skin fibroblasts [28]. These results indicate that HIF- $1 \alpha$ induction by T3 is mediated by TR $\beta / P I 3 K$, similar to ZAKI $4 \alpha$. Other than for ZAKI4 $\alpha$, CHX pretreatment did not prevent HIF- $1 \alpha$ mRNA increase. HIF- $1 \alpha$ is therefore directly induced without the need for prior protein synthesis [28]. Whether this points to direct induction of HIF-1 $1 \alpha$ mRNA synthesis or to activation of constitutively expressed transcription factors needs to be studied.

Lin et al. found HIF- $1 \alpha$ to be induced in $\alpha \mathrm{v} \beta 3$-expressing human glioblastoma cells after treatment with T3 in physiological concentrations [23]. This effect was abrogated by pretreatment with LY. From these results the authors concluded, that T3-induced HIF-1 $\alpha$ expression could be due to PI3K activation via the $\alpha \mathrm{v} \beta 3 / \mathrm{S} 1$ site. Yet, specific data supporting that T3/PI3K-mediated HIF- $1 \alpha$ induction is initiated at the integrin TH receptor, such as reduced T3 effect on HIF-1 $\alpha$ expression after pretreatment with tetrac or RGD peptide, were not provided.

Interestingly, Davis and colleagues also observed a 1.5fold HIF- $1 \alpha$ mRNA increase after T4 stimulation in U-87 MG cells, an effect that seemed to be inhibited by PD pretreatment [23], which raises the possibility that HIF$1 \alpha$ induction could also be mediated by $\alpha v \beta 3 /$ S2/ERK1/2.

\section{HIF-1 target genes}

Besides the $\alpha$-subunit of the transcription factor HIF-1, several of its known target genes, harboring hypoxiaresponse-elements in their promoter regions, were induced by $\mathrm{TH}$ in the same microarray study: glucose transporter 1 (GLUT1), phosphofructokinase (PFKP) and monocarboxylate transporter 4 (MCT4) [9]. Their products have important roles in cellular glucose metabolism: glucose uptake (GLUT1), glycolysis (PFKP) and lactate export (MCT4). The response of GLUT1, PFKP and MCT4 to TH with reproducible mRNA increase after physiological doses of T3, abrogation of this response by pretreatment with LY and lack of a significant response in cells with a mutant TR $\beta$ matches the pattern observed for HIF- $1 \alpha$ and expected for HIF- $1 \alpha$ target genes. In addition to the increase in mRNA, for PFKP an increase could be demonstrated for the protein by western blot. In contrast to HIF-1 $\alpha$, the induction of the PFKP, GLUT1 and MCT4 genes was inhibited by pretreatment with $\mathrm{CHX}$, an inhibitor of protein synthesis. This requirement of prior protein synthesis is expected if their induction is mediated by HIF-1 [28]. 
Stanniocalcin (STC)-1 is a polypeptide hormone and was originally identified as a regulator of calcium/phosphate homeostasis in fish and mammals. In humans, STC1 has been implicated in angiogenesis, apoptosis and carcinogenesis and, recently, SUMOylation [29]. STC1 was recently characterized as a HIF-1 target gene as well [30]. STC-1 expression is inducible by T3, an effect dependent on TR $\beta$ and prior protein synthesis, and inhibited by LY and $\Delta \mathrm{p} 85 \alpha$. STC- 1 therefore also belongs to this set of genes indirectly induced by $\mathrm{TH}$ via TR $\beta /$ PI3K and HIF-1 [31].

\section{MCL1}

Myeloid cell leukemia (MCL) 1 is an anti-apoptotic member of the B-cell lymphoma 2 (Bcl-2) family of apoptosis-regulating proteins. A twofold increase in MCL1 mRNA and protein was observed after treatment with $100 \mathrm{nM}$ T3 in human kindey-2 (HK2) cells [32]. In subsequent promoter studies in HEK293 cells transfected with a luciferase reporter vector containing parts of the MCL1 promoter, treatment with $100 \mathrm{nM}$ T3 in serumfree medium lead to a twofold increase in MCL1 promoter activity measured by a luciferase assay. In HEK293 cells, transcription from the MCL1 promoter also increases twofold in the presence of TR $\beta 1$, but not TR $\alpha 1$. Transcriptional activation seems not to be mediated by a potential TRE-DR4, because it also occurs in the presence of a disrupted TRE-DR4. This effect was abolished by inhibiting PI3K with wortmannin. These results indicate that MCL1 can be induced by T3 and that activation of PI3K and the TR $\beta 1$ are required, compatible with mechanism B (Fig. 1). From a dose response curve, T3 appears to have a significant effect on the MCL1 promoter only with doses of $100 \mathrm{nM}$ and higher. These concentrations are about 100-fold physiological, and rather even higher, considering that serumfree medium instead of medium supplemented with T3-depleted serum was used. This and the fact that the results on the induction mechanism are from promoter studies limit conclusions towards the physiological relevance.

\section{FGF2}

Finbroblast growth factor (FGF) 2 is a member of the fibroblast growth factor (FGF) family and possesses angiogenic activities. In ECV304 cells, Davis et al. observed an increase in FGF2 RNA after stimulation with $100 \mathrm{nM}$ T4 by RT-PCR [33]. FGF2 cDNA accumulation was significantly increased after $6 \mathrm{~h}$ and remained so for additional 42 hours. Treatment with T3 was not tested. In the same cells, T4 stimulated FGF2 secretion, measured by ELISA. This was inhibited by pretreatment with PD. Interestingly, treatment with $10 \mathrm{nM}$ T3 also significantly increased FGF2 secretion and its effect was also inhibited by PD. These results can be interpreted as pointing to induction of FGF2 by T4 and T3 via the S2 site of the integrin TH receptor followed by MAPK activation (Fig. 2D), but involvement of both MAPK and $\alpha v \beta 3$ in FGF2 gene expression still need to be determined specifically.

\section{Conclusion}

TH can act through the TRs $\alpha$ and $\beta$ on TREs, leading to gene induction (classical action), or act through TRs/ PI3K in cytoplasm and nucleus or at the cell membrane on the integrin $\mathrm{TH}$ receptor $\alpha \mathrm{v} \beta 3$ (nonclassical action). These nonclassical actions of TH can lead to truly nongenomic effects, for example activation of the $\mathrm{Na}^{+} / \mathrm{K}$ ${ }^{+}$-ATPase. TH action via $\alpha v \beta 3$ or TR/PI3K can also induce gene expression, e.g. for the genes describe above. These actions therefore constitute nonclassically initiated genomic actions of $\mathrm{TH}$.

Results from most microarray studies so far delivered the sum of genes induced or repressed by $\mathrm{TH}$ without distinction of the mechanisms involved. For our own microarray study of T3 induced gene expression in human fibroblasts [9], we later found several of the most strongly induced genes after $\mathrm{TH}$ treatment to be downstream of TR $\beta / P I 3 K$. Our interpretation was that in the PI3K signal transduction pathway the $\mathrm{TH}$ signal can be amplified from kinase to kinase (e.g. $\mathrm{PI} 3 \mathrm{~K}>\mathrm{AKT}>\mathrm{mTOR}$ ) before reaching the genomic level. Amplification of TH action on a TRE seems limited in comparison.

While it is rather easy to measure $\mathrm{TH}$ induced gene expression, it seems much more complicated to pin down which of the possible mechanisms of $\mathrm{TH}$ action is responsible for the induction. Studies on nonclassical $\mathrm{TH}$ action often suffer from limitations and attribution to pathways and receptors is circumstantial. The connection between pathway and gene is not always complete, as for ZAKI the putative transcription factor linking PI3K and ZAKI4 expression is unknown. Furthermore, results from cells treated with excessive T3 concentrations need to be validated with more physiologic concentrations. The requirement of the $\mathrm{TH}$ receptor (TR or $\alpha v \beta 3$ ) is not always convincingly shown. Nonclassically induced gene expression by $\mathrm{TH}$ would ideally be demonstrated by direct induction of a gene with use of physiologic $\mathrm{TH}$ concentrations, which is abrogated by both inhibiting the pathway and the initial $\mathrm{TH}$ receptor suspected to be involved. Ultimately, the connection of mechanisms of $\mathrm{TH}$ actions, sets of genes and (patho-) physiology is probably much more intricate than the rather simplistic descriptions here suggest. This is demonstrated by HIF-1 $\alpha$ induction, for which three nonclassical mechanisms of $\mathrm{TH}$ action are possibly responsible (TR $\beta / \mathrm{PI} 3 \mathrm{~K}, \alpha \mathrm{v} \beta 3 / \mathrm{S} 1 / \mathrm{PI} 3 \mathrm{~K}$ and $\alpha \mathrm{v} \beta 3 / \mathrm{S} 2 / \mathrm{ERK} 1 / 2)$. 
Further studies of these newly described ways through which TH can modify gene expression may offer new therapeutic possibilities. The groups of Davis, Mousa and Hercbergs provided first examples and demonstrated that tetrac, which inhibits TH action at $\alpha v \beta 3$, reduces growth of medullary thyroid cancer cells and renal cancer cells in mouse xenograft models $[34,35]$.

\section{List of abbreviations}

BTEB1: basic transcription element binding protein 1; CHX: cycloheximide DSCR1L1: down syndrome critical region gene 1-like 1; ERK: extracellular signal-regulated protein kinase; FGF2: fibroblast growth factor 2; GLUT1: glucose transporter 1; HIF-1: hypoxia inducible factor 1; KCNH2: potassium voltage-gated channel: subfamily H (eag-related), member 2; LY: LY249002; MAPK: Mitogen-activated protein kinase; MCL1: myeloid cell leukemia 1; mTOR: mammalian target of rapamycin; PD: PD98059; PFKP: phosphofructokinase, platelet; PI3K: phosphatidylinositol 3-kinase; RCAN2: regulator of calcineurin 2; RTH: resistance to thyroid hormone; RXR: retinoid $X$ receptor; STC1: stanniocalcin 1; T3: triiodothyronine; T4: thyroxine; tetrac, tetraiodothyroacetic acid; TH: thyroid hormone; TR: thyroid hormone receptor; TRE: thyroid hormone response element.

\section{Acknowledgements}

This article has been published as part of Thyroid Research Volume 4 Supplement 1, 2011: New aspects of thyroid hormone synthesis and action. The full contents of the supplement are available online at http://www. thyroidresearchjournal.com/supplements/4/S

\section{Competing interests}

The authors declare that no competing interests exist.

Published: 3 August 2011

\section{References}

1. Yen PM: Physiological and molecular basis of thyroid hormone action. Physiol Rev 2001, 81(3):1097-142.

2. Cheng SY, Leonard JL, Davis PJ: Molecular aspects of thyroid hormone actions. Endocr Rev 2010, 31(2):139-170.

3. Weiss RE, Refetoff $S$ : Resistance to thyroid hormone. Rev Endocr Metab Disord 2000, 1(1-2):97-108.

4. Yen PM: Molecular basis of resistance to thyroid hormone. Trends Endocrinol Metab 2003, 14(7):327-333.

5. Refetoff $S$, DeWind LT, DeGroot LJ: Familial syndrome combining deafmutism, stuppled epiphyses, goiter and abnormally high PBI: possible target organ refractoriness to thyroid hormone. J Clin Endocrinol Metab 1967. 27(2):279-294

6. Takeda K, Sakurai A, DeGroot LJ, Refetoff S: Recessive inheritance of thyroid hormone resistance caused by complete deletion of the proteincoding region of the thyroid hormone receptor-beta gene. J Clin Endocrinol Metab 1992, 74(1):49-55.

7. Chan IH, Privalsky ML: Isoform-specific transcriptional activity of overlapping target genes that respond to thyroid hormone receptors alpha1 and beta1. Mol Endocrinol 2009, 23(11):1758-1775.

8. Visser WE, Heemstra KA, Swagemakers SM, Ozgur Z, Corssmit EP, Burggraaf J, van ljcken WF, van der Spek PJ, Smit JW, Visser TJ: Physiological thyroid hormone levels regulate numerous skeletal muscle transcripts. J Clin Endocrinol Metab 2009, 94(9):3487-3496.

9. Moeller LC, Dumitrescu AM, Walker RL, Meltzer PS, Refetoff S: Thyroid hormone responsive genes in cultured human fibroblasts. J Clin Endocrinol Metab 2005, 90(2):936-943.

10. Weitzel JM, Hamann S, Jauk M, Lacey M, Filbry A, Radtke C, Iwen KA, Kutz S, Harneit A, Lizardi PM, Seitz HJ: Hepatic gene expression patterns in thyroid hormone-treated hypothyroid rats. J Mol Endocrinol 2003, 31(2):291-303.

11. Morte B, Ceballos A, Diez D, Grijota-Martinez C, Dumitrescu AM, Di Cosmo C, Galton VA, Refetoff S, Bernal J: Thyroid hormone-regulated mouse cerebral cortex genes are differentially dependent on the source of the hormone: a study in monocarboxylate transporter-8- and deiodinase-2-deficient mice. Endocrinology 2010, 151(5):2381-2387.

12. Feng $X$, Jiang $Y$, Meltzer $P$, Yen PM: Thyroid hormone regulation of hepatic genes in vivo detected by complementary DNA microarray. Mol Endocrinol 2000, 14(7):947-955.

13. Cao X, Kambe F, Moeller LC, Refetoff S, Seo H: Thyroid hormone induces rapid activation of Akt/protein kinase B-mammalian target of rapamycinp70S6K cascade through phosphatidylinositol 3-kinase in human fibroblasts. Mol Endocrinol 2005, 19(1):102-112

14. Lei J, Mariash CN, Ingbar DH: 3,3',5-Triiodo-L-thyronine up-regulation of $\mathrm{Na}, \mathrm{K}$-ATPase activity and cell surface expression in alveolar epithelial cells is Src kinase- and phosphoinositide 3-kinase-dependent. J Biol Chem 2004, 279(46):47589-600.

15. Storey NM, O'Bryan JP, Armstrong DL: Rac and Rho mediate opposing hormonal regulation of the ether-a-go-go-related potassium channel. Curr Biol 2002, 12(1):27-33.

16. Storey NM, Gentile S, Ullah H, Russo A, Muessel M, Erxleben C, Armstrong DL: Rapid signaling at the plasma membrane by a nuclear receptor for thyroid hormone. Proc Natl Acad Sci U S A 2006, 103(13):5197-5201.

17. Furuya F, Hanover JA, Cheng SY: Activation of phosphatidylinositol 3kinase signaling by a mutant thyroid hormone beta receptor. Proc Nat Acad Sci U S A 2006, 103(6):1780-5.

18. Cao X, Kambe F, Yamauchi M, Seo H: Thyroid-hormone-dependent activation of the phosphoinositide 3-kinase/Akt cascade requires Src and enhances neuronal survival. Biochem J 2009, 424(2):201-209.

19. Hiroi $Y$, Kim HH, Ying H, Furuya F, Huang Z, Simoncini T, Noma K, Ueki $K$, Nguyen NH, Scanlan TS, Moskowitz MA, Cheng SY, Liao JK: Rapid nongenomic actions of thyroid hormone. Proc Natl Acad Sci U S A 2006, 103(38):14104-14109.

20. Bergh JJ, Lin HY, Lansing L, Mohamed SN, Davis FB, Mousa S, Davis PJ: Integrin alphaVbeta3 contains a cell surface receptor site for thyroid hormone that is linked to activation of mitogen-activated protein kinase and induction of angiogenesis. Endocrinology 2005, 146(7):2864-2871.

21. Mousa SA, Davis FB, Mohamed S, Davis PJ, Feng X: Pro-angiogenesis action of thyroid hormone and analogs in a three-dimensional in vitro microvascular endothelial sprouting model. Int Angiol 2006, 25(4):407-413.

22. Davis PJ, Davis FB, Mousa SA, Luidens MK, Lin HY: Membrane Receptor for Thyroid Hormone: Physiologic and Pharmacologic Implications. Annu Rev Pharmacol Toxicol 2011, 10(51):99-115.

23. Lin HY, Sun M, Tang HY, Lin C, Luidens MK, Mousa SA, Incerpi S, Drusano GL, Davis FB, Davis PJ: L-Thyroxine vs. 3,5,3'-triiodo-L-thyronine and cell proliferation: activation of mitogen-activated protein kinase and phosphatidylinositol 3-kinase. Am J Physiol Cell Physiol 2009, 296(5): C980-91.

24. Davis FB, Tang HY, Shih A, Keating T, Lansing L, Hercbergs A, Fenstermaker RA, Mousa A, Mousa SA, Davis PJ, Lin HY: Acting via a cell surface receptor, thyroid hormone is a growth factor for glioma cells. Cancer Res 2006, 66(14):7270-5.

25. Lin HY, Tang HY, Shih A, Keating T, Cao G, Davis PJ, Davis FB: Thyroid hormone is a MAPK-dependent growth factor for thyroid cancer cells and is anti-apoptotic. Steroids 2007, 72(2):180-187.

26. Miyazaki T, Kanou Y, Murata Y, Ohmori S, Niwa T, Maeda K, Yamamura H, Seo H: Molecular cloning of a novel thyroid hormone-responsive gene, ZAKI-4, in human skin fibroblasts. J Biol Chem 1996, 271(24):14567-14571

27. Semenza GL: Defining the role of hypoxia-inducible factor 1 in cancer biology and therapeutics. Oncogene 2010, 29(5):625-634.

28. Moeller LC, Dumitrescu AM, Refetoff S: Cytosolic action of thyroid hormone leads to induction of hypoxia-inducible factor-1alpha and glycolytic genes. Mol Endocrinol 2005, 19(12):2955-2963.

29. Dos Santos MT, Trindade DM, Goncalves KD, Bressan GC, Anastassopoulos F, Yunes JA, Kobarg J: Human stanniocalcin-1 interacts with nuclear and cytoplasmic proteins and acts as a SUMO E3 ligase. Mol Biosyst 2011, 7(1):180-193.

30. Law AY, Ching LY, Lai KP, Wong CK: Identification and characterization of the hypoxia-responsive element in human stanniocalcin-1 gene. Mol Cell Endocrinol 2010, 314(1):118-127.

31. Moeller LC, Haselhorst NE, Dumitrescu AM, Cao X, Seo H, Refetoff S, Mann K, Janssen OE: Stanniocalcin 1 Induction by Thyroid Hormone Depends on Thyroid Hormone Receptor beta and Phosphatidylinositol 3-kinase Activation. Exp Clin Endocrinol Diabetes. 2011, 119(2):81-85. 
32. Pietrzak M, Puzianowska-Kuznicka M: Triiodothyronine utilizes phosphatidylinositol 3-kinase pathway to activate anti-apoptotic myeloid cell leukemia-1. J Mol Endocrinol 2008, 41(3):177-186.

33. Davis FB, Mousa SA, O'Connor L, Mohamed S, Lin HY, Cao HJ, Davis PJ: Proangiogenic action of thyroid hormone is fibroblast growth factordependent and is initiated at the cell surface. Circ Res 2004, 94(11):1500-6

34. Yalcin M, Bharali DJ, Lansing L, Dyskin E, Mousa SS, Hercbergs A, Davis FB, Davis PJ, Mousa SA: Tetraidothyroacetic acid (tetrac) and tetrac nanoparticles inhibit growth of human renal cell carcinoma xenografts. Anticancer Res 2009, 29(10):3825-3831.

35. Yalcin M, Dyskin E, Lansing L, Bharali DJ, Mousa SS, Bridoux A, Hercbergs AH, Lin HY, Davis FB, Glinsky GV, Glinskii A, Ma J, Davis PJ, Mousa SA: Tetraiodothyroacetic acid (tetrac) and nanoparticulate tetrac arrest growth of medullary carcinoma of the thyroid. J Clin Endocrinol Metab 2010, 95(4):1972-1980.

36. Moeller LC, Cao X, Dumitrescu AM, Seo H, Refetoff S: Thyroid hormone mediated changes in gene expression can be initiated by cytosolic action of the thyroid hormone receptor beta through the phosphatidylinositol 3-kinase pathway. Nucl Recept Signal 2006, 4:e020.

doi:10.1186/1756-6614-4-S1-S6

Cite this article as: Moeller and Broecker-Preuss: Transcriptional

regulation by nonclassical action of thyroid hormone. Thyroid Research 2011 4(Suppl 1):S6.

\section{Submit your next manuscript to BioMed Central and take full advantage of:}

- Convenient online submission

- Thorough peer review

- No space constraints or color figure charges

- Immediate publication on acceptance

- Inclusion in PubMed, CAS, Scopus and Google Scholar

- Research which is freely available for redistribution

Submit your manuscript at www.biomedcentral.com/submit 